\title{
健康新生兒血漿蛋白質の電気泳動法的研究
}

熊本聥信病院小览科

$$
\text { 橋 元 祐 = }
$$

熊本大学医学部小児科教室

(指導教授 長野祐憲)

緒方昌一

\section{Electrophoretical Study on Bloodplasma of Healthy Newborns}

\section{By}

Chizuko Nagayoshi, Yuji Hashimoto

(Dept. of Pediatrics, Kumamoto Communication Hospital)

\section{Masakazu Ogata}

(Dept. of Pediatrics, Kumamoto Univ., Chief ; S. Nagano)

The results of an electropholetical study on 15 healthy newborns, with Tiselius' apparatus (Type HT-B, Hitachi made) are as follows:

Pooled plasma were dialyzed for $16-20$ hours, before electrophoresis, against $1 / 20 \mathrm{M}$ phosphate buffer. Experimental conditions were were as follows: electric voltage $90-130 \mathrm{~V}$., electric current 7.5-11 mA., time $45-70$ minutes, temperature at $3-16^{\circ} \mathrm{C}$., Diagonal-slit angle $25^{\circ}$.

When compared with children,

1) total protein showed remarkable decrease,

2) albumin little or no decrease,

3) globulin remarkable decrease,

4) $\alpha$-globulin remarkable decrease,

5) $\beta$-globulin remarkable decrease,

6) $\gamma$-globulin little decrease or nothing,

7) fibrinogen decrease,

8) $\mathrm{A} / \mathrm{G}$, increase,

9) $\alpha-G / A$, decrease,

10) $\gamma-G / A$ and $\gamma-G / T . P$. showed no remarkable differences.

\section{I. 緒言}

先に我々は健康奻览血漿蛋白質の電気泳動法による研 究成績を発表したが，新生児血液は一般小児の夫と，形 態学的にも生化学的にも著明な差異を有することは既知 の事柄である。血漿蛋白も恐らく著しい差異のあるこ とは想像に難くないので, 前回の研究に引続き, 健康新 生児つ血漿蛋白に就いて検査した結果を報告したい。

\section{II. 実 験 方 法}

1）実験対象は熊本逓信病院産婦人科に大院した産婦上 り分婏された新生児15名で, その臍帯血を婏出直後に
採血，二重荷酸塩を以て血漿を分離した。

2）実験方法は前回報告と同樣。

\section{III. 実 験 成 績}

血漿蛋白量, 各分屑値, 分屑比率, 泳動条件它の他を 一括表示すれば, 第1表の如くである。

\section{IV. 総括竝びに考按}

新生見の血漿が形態的にも，生化学的にも，成人は勿 論小巟や幼罗と著しい差異があることは申す迄もない。 血嶈蛋白も亦同梯に相違が想像されるが，如何なる差異 が見られるかを上述の成績と前回の幼児の成績とを比較 


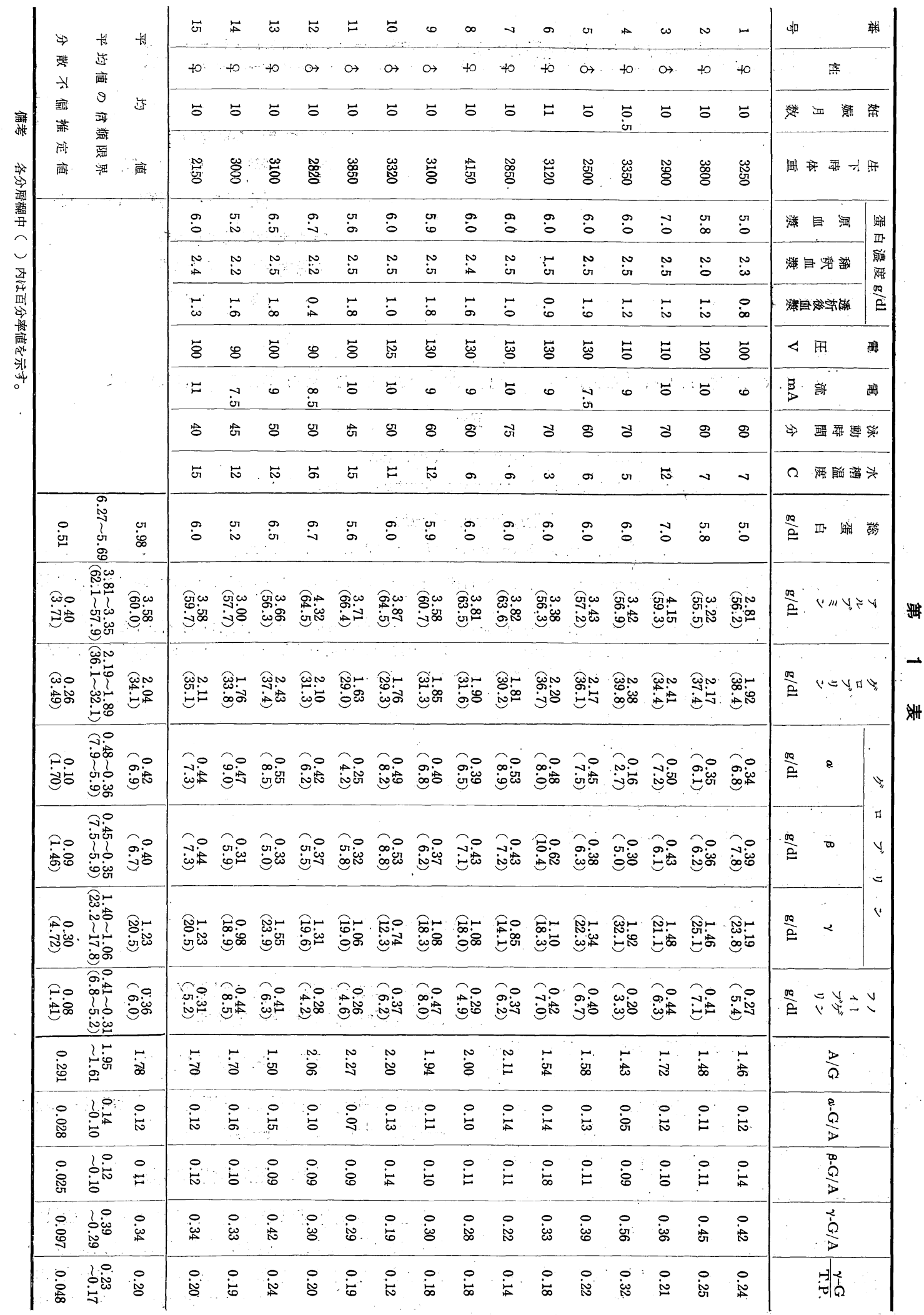


し, 推計学的に検討してみた。郎ち, 両群の総蛋白量, 各分屑量及び分原比率の平均値及び分散不偏推定值を算 出し，分散の同非を $\mathbf{F}$ 检定洗で検定した後，平均値の差 を $\mathrm{t}$ 検定洗でその有意性を検定した。告険率は一般に 1 \%としたが, $5 \%$ \%とつた場合もある。（ $r \mathrm{G}-, \mathrm{A} / \mathrm{G}, r-\mathrm{G}$ /A， $\gamma-G / T . P$.$) な打， \alpha-G$ 文び $\alpha-G / A$ に就いては前報 告で述べた樣に健康幼児の值としては B幼稚園群の值を 採用した。これ等の数值を一括すれば第 2 表の如くであ る。

以上の結果を綜合判断すると

1），総蛋白量は幼児に比較して，- 新生見に於ては著明 な低值を示している。

2) Albumin はやや低值を示すが, 我々の得た $t=$ 2.832 飞対して; $t(0.05,35)=2.03, t(0.01,35)=$ 2.73 であるから，著しい差とは言い切れない。

3) Globulin は著明な低值を示す。

4） $\alpha$-Globulin は著明な低值を示す。
5） $\beta$-Globulin は著明な低値を示与。

6). $\gamma$-Globumin はやや低い俌を示しているが, 我及 の得た $t=2.167$ に対して $t(0.05,32)=2.04, \ddot{t}(0.01$, $32)=2.75$ であるがら，著しい差があるとは言い切 れない。

7）Fibrinogen 以低值を示す。

8) $\mathrm{A} / \mathrm{G}$ は $F=3.30$ を得たが，これに対して $F_{18}^{14}$ $(0.05) \fallingdotseq 2.28, F_{18}^{14}(0.01) \fallingdotseq 3.25$ であるから分散が等 しいと言えない。従つて，新生睍と幼览の比較は困 難であるが， $F$ 值が略等しいので，仮に分散が同一 と又.て, $t$ 検定を行うと， $t=4.720$ が得られ，これ に詨して $t(0.05,32)=2.04, t(0.01,32) \doteqdot 2.75$ て 必るから有意な差があると考台られる。

9） $\alpha-G / A$ は小で女る。

10） $\beta-\mathrm{G} / \mathrm{A}$ は小である。

11） $\gamma-G / A$.は新生児, 幼览間以有意な差は認められ ない。

第 2 表

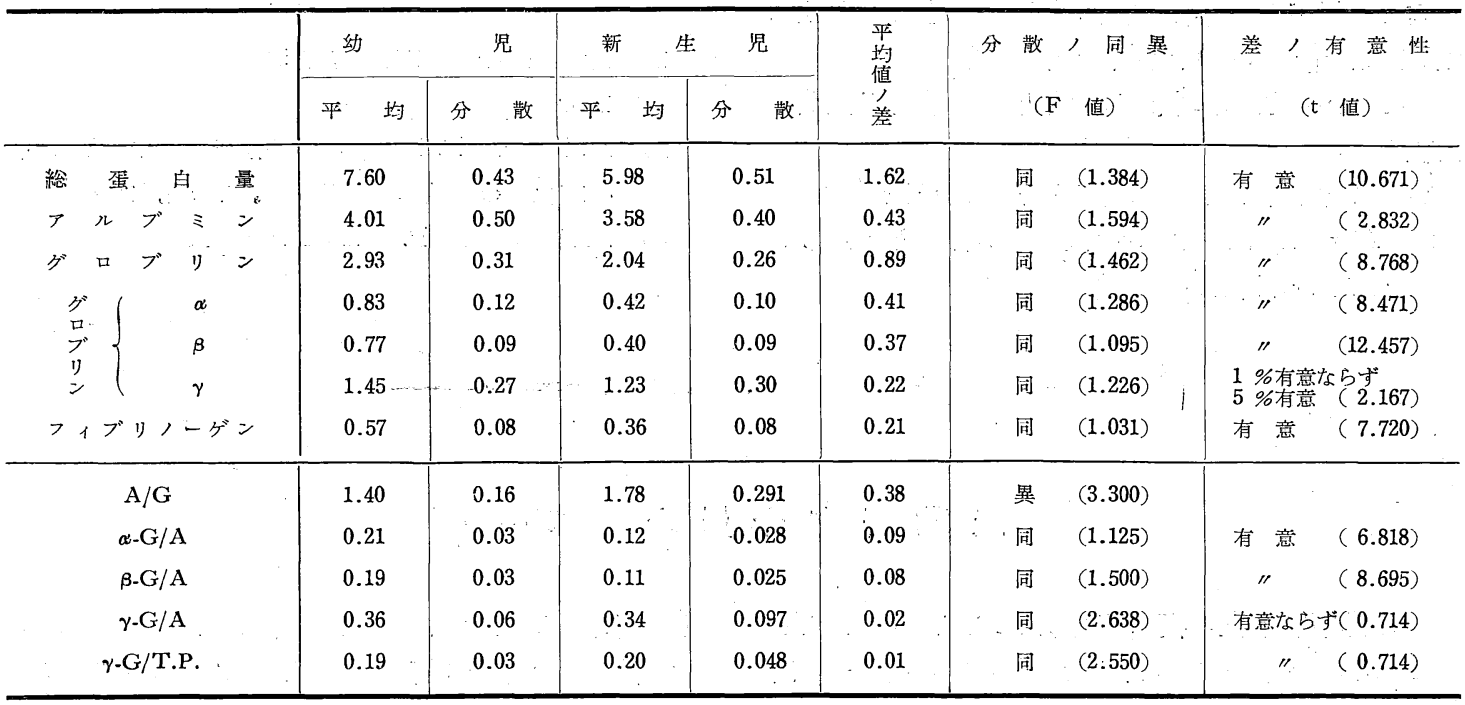

第 3 ，表

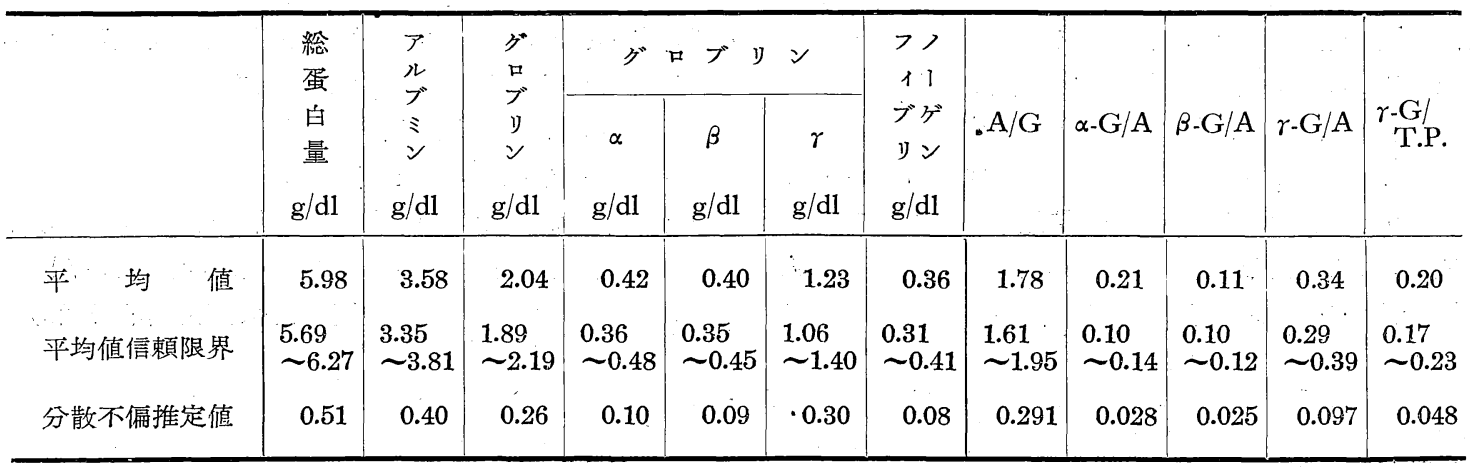


12） $\gamma-\mathrm{G} / \mathrm{T}$.P. ๖両者間に有意な差は認められない。 以上を要するに, Albumin 及び $\gamma$-Globumin は新生 児が特に低い值を示すと断定出来ないが，総蛋白量站び にその他の分原は明に低い值を示している。この現象は 動物間にも認められる。郎ち，Polson に拠れば10才馬 では蛋白質量は $7 \%$ であるに対して新生馬では $3.7 \%$ で おり, Albumin, $\alpha-, \beta$ - 及び $\gamma$-Globulin 含有量は成 長馬では夫々 30，11，12及び47\%に対し新生馬の夫は, 65，32，3 文び $0 \%$ であると云う。要た Haurowitz, Schwerin によれば，生れたての鬼の血清には $0.2 \%$ の Globulin と 4.8\% の Albumin を含むに過ぎない と云う。ると.上り人類と他動物を直接比較することは出 来ないが，興味あることである。新生児に於て，Albu一 min 及び $r-G$ が左程少くない現象は, Albumin が成 長と最も密接な関係があり, また新生罗が先天免疫を獲 得していることと梁い関係がある様に考兄られるが，さ らに深く研究すべきものと思う。

\section{V: 結 論}

健康新生児15例に就いて, 脳帯血漿蛋白質の電気泳動 法的研究を行い, 第 3 表の如き成績を得た。

これ等の結果を先に報告した健康小児に於ける成績と 比較するに,

1）総蛋白量は新生巟に於ては著明な低値を示す。

2）Albumin はやや低い值を示すが著明な差がある とは言い切れない。
3）Globulin は著明な低值を示与。

4） $\alpha$-Globulin は著明な低值を示す。

5） $\beta$-Globulin は著明な低值を示す。

6） $\gamma$-Globulin は低い值を示すが，著しい差がある とは言い切れない。

7) Fibrinogen は低い值を示す。

8) $\mathrm{A} / \mathrm{G}$ は分散が同一でないから，直に比較し得ない が，大であると言えると思う。

9） $-\mathrm{G} / \mathrm{A}$ は小である。

10） $\beta-G / A$ は小である。

11） $r-G / A$ 及び $\gamma-G / T . P$. は幼児，新生児間に有意 な差は認め難い。

（擱筆に当り，恩師長野教授立立びに長眘熊本派信病院長 の御校閲を深謝し, 吉尾産婦人科部長, 竹屋臨床検査科 長の御授助を感謝する。な括, 本論文の要旨は第52回九 州医学会小昌科分科会に於て発表した。末た，本研究は 電気通信省医学研究費に負う所が多かつた。記して感謝 の意を表する。)

\section{文献}

1) 橋元, 永好, 緒方; 生物物理化学, 1巻, 2号, 123頁 1952

2) A. Polson, F. Haurowiz 著, 広田猛夫訳 生物 物理化学の領域に於ける蛋白, 150頁, 1950

3) F. Haurowiz, P. Schwerin; 同上

\section{“泳動 研究会員として…..."}

私は血漿蛋白質を専門に勉強したことはない。ふとし たことで電気泳動研究会の運営について, 平井博士を助 けてゆく立場におかれて，今まで努力をつづけてきた。 その抢かげで, 毎回の研究会に出席させてもらい, 血漿 蛋白質の研究がいかに重大であるかを知ることができ た。このことを一般の実地医家にも知つてもらいたいと いら意図で, 数回日本医事新報に研究会出席の記を書い たこともあつたが，その度ごとに，電気泳動とは一体ど のようなことをするのかという質問がまいこんできて当 惑することが何回かあつた。こんなときはいつも，基礎 医学者は自分自身の枠の中にとぢこもつて、ひとりよが
りの研究にうき身をやつしている傾向はないか，あるい は自分自身の研究が臨床にどのように生きているかとた 党ず反省しているだろらか，というょうなことを考えて みるのが常であつた。最近, 私どもの研究会のなかで, 臨床医家が最も岕りふれた検査の手段として応用してい る血沈を中心にした討論がきわめて盛んなようである が、これなどは非常に喑ばしい現像だと信じている。

基礎医学者は，もつと臨床畑のなかへとびこんで, 早 近な臨床的事実の解釈に自己の専門知識を生かしてゆく ことに生甲斐を感ずるべきであると私は信じている。

（慈恵医大生理 阿部正和） 